Rapp. Grønlands geol. Unders. 99, 153-154 (1980)

\title{
PRELIMINARY BOUGUER ANOMALIES \\ OF WESTERN NORTH GREENLAND
}

Willy Lehmann Weng

During the summer of 1979 the Geodetic Institute, Copenhagen, continued the North Greenland survey, which was initiated in 1978 (Forsberg, 1979). This comprised establishment of ground control points by help of Doppler instruments combined with barometric, triangulation and doppler-derived heights as vertical control. During 1979, as a minor part of the surveying programme, a regional gravity net-work was established for the area between Hall Land and Nansen Land (fig. 66).

Bouguer anomalies have been computed as part of the preliminary examination of the data. Three major sources of errors exist: (1) lack of density determinations in the area, (2) preliminary nature of the barometric heights used, and (3) absence of terrain corrections. The preliminary values may deviate $15 \mathrm{mgal}$ from the accurately corrected anomalies.

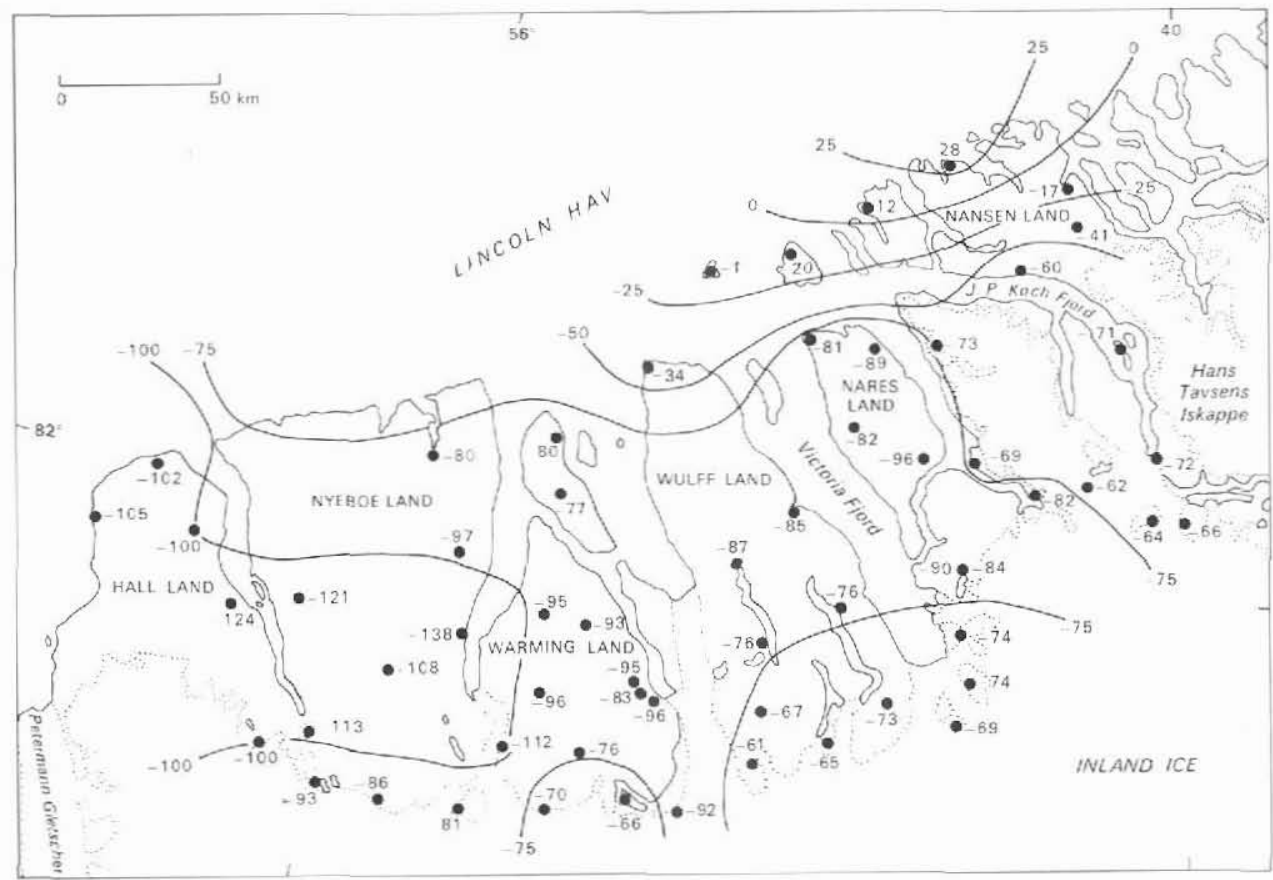

Fig. 66. Preliminary Bouguer anomaly map of northern Greenland between Petermann Gletscher and $40^{\circ}$ W. Datum IGSN71. Reference GRS67. Density $2.67 \mathrm{~g} / \mathrm{cm}^{3}$. Values in mgal. No terrain corrections applied. 
The Bouguer anomaly map shown in fig. 66 displays a pattern with coast parallel contours, similar to other parts of the Greenland coast. The anomalies decrease from the Lincoln Hav towards the ice cap, and in this area the minimum is reached c. $50 \mathrm{~km}$ north of the ice cap. A gravity-valley with the bottom sloping from $-70 \mathrm{mgal}$ at J. P. Koch Fjord down to $-\mathbf{1 2 5} \mathrm{mgal}$ in central Hall Land is traceable through the region from east to west. In Nansen Land the anomalies increase northwards and reach a maximum of $+28 \mathrm{mgal}$ at the north coast.

\section{Reference}

Forsberg, R. 1979: A gravity map of Peary Land, North Greenland. Rapp. Grønlands geol. Unders. 88, 93-94. 